\title{
ALK-rearrangements and testing methods in non-small cell lung cancer: a review
}

\author{
Rodney E. Shackelford ${ }^{1}$, Moiz Vora ${ }^{1}$, Kim Mayhall ${ }^{2}$, and James Cotelingam ${ }^{1}$ \\ 1 LSU Health Shreveport, Department of Pathology, Shreveport, LA, USA \\ 2 Tulane University School of Medicine, New Orleans, LA, USA \\ Correspondence to: Rodney E. Shackelford, email: rshack@Isuhsc.edu \\ Keywords: Anaplastic lymphoma kinase, non-small cell lung cancer, pulmonary adenocarcinoma, crizotinib \\ Received: December 15, $2013 \quad$ Accepted: April 22, $2014 \quad$ Published: April 22, 2014
}

This is an open-access article distributed under the terms of the Creative Commons Attribution License, which permits unrestricted use, distribution, and reproduction in any medium, provided the original author and source are credited.

\section{ABSTRACT:}

The anaplastic lymphoma tyrosine kinase (ALK) gene was first described as a driver mutation in anaplastic non-Hodgkin's lymphoma. Dysregulated ALK expression is now an identified driver mutation in nearly twenty different human malignancies, including 4-9\% of non-small cell lung cancers (NSCLC). The tyrosine kinase inhibitor crizotinib is more effective than standard chemotherapeutic agents in treating ALK positive NSCLC, making molecular diagnostic testing for dysregulated ALK expression a necessary step in identifying optimal treatment modalities. Here we review ALKmediated signal transduction pathways and compare the molecular protocols used to identify dysregulated ALK expression in NSCLC. We also discuss the use of crizotinib and second generation ALK tyrosine kinase inhibitors in the treatment of ALK positive NSCLC, and the known mechanisms of crizotinib resistance in NSCLC.

\section{INTRODUCTION}

Lung cancer is the leading cause of cancer deaths world-wide [1]. Approximately $85 \%$ are non-small cell lung cancers (NSCLC), consisting mainly of squamous cell, adenocarcinoma, adenosquamous carcinoma, and large-cell anaplastic carcinoma, with most being adenocarcinomas $[2,3]$. Roughly $85 \%$ of lung cancers are caused by smoking, with the remaining related to factors such as individual genetics, and radon gas, asbestos, and air pollution exposures [2-4]. Most NSCLCs are diagnosed at an advanced stage, are clinically aggressive, and have a high metastatic potential. Thus NSCLC has a poor prognosis, with the majority of newly diagnosed individuals surviving less than one year and the five year survival rate being $16 \%$ [5]. Additionally, current NSCLC chemotherapeutic regimens have low efficacy. For example, patients with untreated advanced NSCLC have a median survival of 7.15 months, while those treated with current platinum-based doubled chemotherapy regimens have an 8-12 month median survival $[4,5]$.

Over the past ten years intense research into the mechanisms of carcinogenesis and malignant progression has revealed that $\sim 140$ genes are altered in human malignancies, functioning as "driver mutations" that initiate and maintain malignancy [6]. While most adult malignancies carry 33-66 driver mutations, NSCLCs carry $\sim 200$ mutations, probably due to their arising in a background of cigarette smoke mutagen exposure [6]. Not surprisingly, lung cancers in non-smokers have 10fold fewer mutations than those in smokers [7]. Presently, at least eighteen different driver mutations have been identified in NSCLC [8-38]. Thus, tumors once viewed as common "generic histologic types" are by molecular analysis composed of many tumor subtypes with similar histologies, but different molecular mechanisms of carcinogenesis and possible treatment modalities [38]. For example, epidermal growth factor receptor (EGFR]) gene mutations are found in $15-30 \%$ in NSCLCs and are an indication for tyrosine kinase inhibitor (TKI, erlotinib or gefitinib) therapy $[38,39]$. Several NSCLC mutations, such as the V600E and G479A BRAF mutations, are found in only $1-3 \%$ of NSCLCs and are tested for less frequently [38,40]. Most current molecular NSCLC testing is directed at EGFR, KRAS, and ALK mutation detection [38]. Specific therapeutic regimens exist for NSCLCs with EGFR, BRAF, and ALK mutations [38,39,41]. Presently KRAS mutations are undruggable, although benzimidazole compounds are being developed which inhibit oncogenic RAS signaling and suppress the in vivo 
and in vitro growth of pancreatic adenocarcinoma cells at nM concentrations [42].

Typically, the TKIs are used for locally advanced or metastatic NSCLC, or for NSCLC treatments that have failed standard chemotherapeutic regimens $[43,44]$. TKI therapy has little effect on malignancies lacking the driver mutation for specific TKI targets. For example, in patient populations with NSCLC unselected for EGFR mutations, the response rate to EGFR mutation-directed TKI therapy is $\sim 9 \%[45,46]$. In NSCLC patients with EGFR mutations the response rates to erlotinib or gefitinib are greater than $70 \%[47,48]$. Based on this, molecular diagnostic testing for ALK and EGFR mutations is now recommended for NSCLCs to guide therapy $[48,49]$. Here we review the basic molecular pathology of ALK gene function in NSCLC, current testing methods, and review the current treatment strategies directed at ALK-mutation positive NSCLC.

\section{Anaplastic Lymphoma Kinase Gene Signaling}

The anaplastic lymphoma kinase (ALK) gene is found at 2p23, spans 29 exons, and encodes a 1,620 amino acid, $220 \mathrm{kDa}$ classical insulin superfamily tyrosine kinase. The mature ALK protein undergoes posttranslational $\mathrm{N}$-linked glycosylation and consists of an extracellular ligand-binding domain, a transmembrane domain, and a single intracellular tyrosine kinase domain. ALK is activated by dimerization with subsequent transautophosphorylation of three tyrosine moieties [50]. ALK is expressed in central and peripheral nervous systems, testes, skeletal muscle, basal layer keratinocytes, and small intestine. ALK appears to function in neuronal development and differentiation during embyrogenesis and its expression falls to low-levels at age three weeks and remains low throughout adult life [50-56]. Little is known about normal physiologic ALK function and ALK-/- mice show age-related increases in hippocampal progenitor cells, mild behavioral alterations, full viability, and have a normal lifespan [51,57]. In D. melanogaster and $C$. elegans the ALK-activating ligands Jelly belly and hesitation behavior have been identified, respectively $[58,59]$. In humans the heparin-binding growth factors Midkine and Pleiotrophin bind ALK have been reported to be the mammalian activating ligands $[60,61]$. However multiple studies have failed to confirm these results, so the endogenous ALK ligand remains controversial [20,62-65].

Activated ALK initiates several signal transduction pathways, including the Janus kinase, mammalian target of rapamycin, sonic hedgehog, phosphoinositide 3-kinase/ protein kinase B, hypoxia-inducible factor-1 $\alpha$, JUNB, and phospholipase $\mathrm{C} \gamma$ signaling. ALK signaling also regulates miR135b, mi29a, and miR-16, while Alk itself is regulated by miR-96 [50]. Analyses of ALK-signaling are complicated by the fact that different studies have employed different models, some of which examined wild-type ALK activity and others examining different ALK fusion protein activities. Thus, it's likely that some fusion protein targets do not represent "wild-type" or legitimate ALK phosphorylation targets [50].

\section{ALK Mutations in Cancer}

ALK was first identified by Morris et al. (66) in anaplastic non-Hodgkin's lymphoma (ALCL), where it's fused to nucleophosmin, forming a $\mathrm{t}(2 ; 5)(\mathrm{p} 23 ; \mathrm{q} 35)$ chromosomal translocation with constitutively active ALK kinase activity. Since this study activating ALK kinase mutations/translocations have been identified in a number of malignancies (Table 1) $[8,9,50,56,66-$ 97]. For many of these tumors, only a low percent are ALK positive [80,81]. ALK activation occurs largely through three different mechanisms: 1) fusion protein formation, 2) ALK over-expression, and 3) activating ALK point mutations [50]. While most histologicallydefined tumor types have one of these mutation types, a few like the inflammatory myofibroblastic tumor (IMT) and NSCLC can have ALK mutations in two categories (Table 1). In the ALK translocations, the fusion partner regulates ALK expression levels, its subcellular location, and when it's expressed. Presently, there are 22 known different translocation partners that form fusion proteins with ALK [50]. In many cases, such as the echinoderm microtubule-associated protein-like 4 (EML4)-ALK fusion found in NSCLC, there are multiple fusion variants with different molecular weights, frequencies in NSCLC, protein stabilities $\left(\mathrm{t}_{1 / 2}\right)$, and ALK inhibitor sensitivities [50,70,98,99] (Table 2). Rare individuals with non-functioning kinase ALK mutations have been identified. Presently it is unclear if these ALK "kinase dead" mutations promote tumor growth or are "passenger mutations" that do not effect cell proliferation [100].

\section{ALK Activity in NSCLC}

ALK was first identified in NSCLC by Soda et al. and Rikova et al. [8,9]. Rikova et al. [9] used global phosphotyrosine analysis to examine 41 NSCLC cell lines and 150 NSCLC tumors. Phospho-tyrosine peptides from these samples were purified and analyzed for specific phosphotyrosine kinase patterns. Patterns were detected for EGFR, c-Met, PDGFR- $\alpha$, ROS, DDR1, and EML4ALK and TGF-ALK fusion protein activities, with $4.4 \%$ of the NSCLCs being ALK fusion protein positive. Soda et al. [8] employed a retroviral cDNA expression library derived from a lung adenocarcinoma specimen which was infected into murine fibroblasts. One clone corresponded to the amino portion of EML4 and the carboxy portion of human ALK. Of 75 NSCLCs later examined 5 (6.7\%) 
Table 1: A list of the human malignancies known to express ALK dysregulated protein

\begin{tabular}{|c|c|c|c|}
\hline Tumor Type & ALK Alteration & ALK Mutation Frequency & References \\
\hline $\begin{array}{l}\text { Anaplastic } \\
\text { Non-Hodgkin's } \\
\text { Lymphoma (ALCL) }\end{array}$ & \begin{tabular}{|l|}
$\mathrm{t}(2 ; 5) \quad$ ALK- \\
Nucleophosmin \\
chromosomal \\
translocation
\end{tabular} & $\begin{array}{l}\text { 60-85\% of ALCLs are ALK positive, rare fusions with } \\
\text { TPM3, TPM4, TFG, ATIC, CLTC, MSN, MYH9, and } \\
\text { ALO17 }\end{array}$ & {$[66-69]$} \\
\hline $\begin{array}{l}\text { Non-Small Cell } \\
\text { Lung Cancer }\end{array}$ & \begin{tabular}{|l|} 
Chromosomal \\
inversion/ \\
translocation on 2p \\
fusing EML4-ALK
\end{tabular} & $\begin{array}{l}\text { 3-7\% of NSCLC are ALK positive, } 21 \text { known EML4-ALK } \\
\text { breakpoints variants exist, rare fusions exist with TGF, } \\
\text { KLC1, and KIKF5B }\end{array}$ & {$[8,9,50,70,71]$} \\
\hline $\begin{array}{l}\text { Basal } \\
\text { Carcinoma }\end{array}$ & ALK over-expression & $\begin{array}{l}250 \text {-fold increased phospho-ALK expression in } \sim 100 \% \text { of } \\
\text { BCCs }\end{array}$ & {$[56]$} \\
\hline Breast Cancer & EML4-ALK fusion & $\begin{array}{l}2.4 \% \text { fusion positive by exon array profiling, } 80 \% \text { of } \\
\text { inflammatory breast cancers show increased ALK protein }\end{array}$ & {$[72,73]$} \\
\hline Neuroblastoma & ALK over-expression & $\begin{array}{l}\text { ALK over-expressed in over } 50 \% \text { of tumors, } \sim 12.4 \% \text { of } \\
\text { tumors carry activating ALK point mutations which are } \\
\text { also common in familial neuroblastoma }\end{array}$ & {$[74-76]$} \\
\hline $\begin{array}{l}\text { Colorectal } \\
\text { Carcinoma }\end{array}$ & EML4-ALK fusion & $2.4 \%$ fusion positive by exon array profiling & {$[72]$} \\
\hline $\begin{array}{l}\text { Inflammatory } \\
\text { Myofibroblastic } \\
\text { Tumor (IMT) }\end{array}$ & $\begin{array}{l}\text { Several ALK fusion } \\
\text { proteins }\end{array}$ & $\begin{array}{l}\sim 50 \% \text { of IMTs are ALK positive, fusion partners include } \\
\text { CLTC, TPM3, TPM4, CLTC, CARS, ATIC, RANBP2, and } \\
\text { SEC31L1. Activating ALK point mutations also occur. }\end{array}$ & {$[50,77-79]$} \\
\hline $\begin{array}{l}\text { Diffuse large B-Cell } \\
\text { Lymphoma }\end{array}$ & $\begin{array}{|ll|}\begin{array}{l}\text { Several ALK fusion } \\
\text { proteins }\end{array} & \\
\end{array}$ & $\begin{array}{l}\text { Rare, with } \sim 50 \text { cases described. The most common fusions } \\
\text { partners are CLTC and NPM. }\end{array}$ & {$[80,81]$} \\
\hline Glioblastoma & ALK over-expression & $\begin{array}{l}\text { ALK is over-expressed, lowering ALK expression } \\
\text { decreases glioblastoma tumor growth }\end{array}$ & {$[51,52]$} \\
\hline Renal Carcinomas & Several translocations & $\begin{array}{l}\text { ALK translocations with EML4, TPM3, and VCL fusion } \\
\text { partners, the translocations appear to occur at a low } \\
\text { frequency }\end{array}$ & {$[83-87]$} \\
\hline $\begin{array}{ll}\text { Esophageal } & \\
\text { Squamous } & \text { Cell } \\
\text { Carcinoma } & \\
\end{array}$ & TPM4-ALK fusion & $\begin{array}{l}\text { TPM4-ALK fusion oncoprotein type } 2 \text { found in } \sim 20 \% \text { of } \\
\text { cases }\end{array}$ & {$[88]$} \\
\hline Ewing's Sarcoma & ALK over-expression & $\begin{array}{l}\text { Moderate to high ALK positivity was found in the majority } \\
\text { of tumors }\end{array}$ & {$[89,90]$} \\
\hline Ovarian Cancer & ALK over-expression & $\begin{array}{l}\text { ALK over-expressed in } 2-4 \% \text { of ovarian cancers, one } \\
\text { stromal sarcoma carried a FN1-ALK fusion protein }\end{array}$ & {$[91]$} \\
\hline $\begin{array}{l}\text { Anaplastic Thyroid } \\
\text { Carcinoma }\end{array}$ & $\begin{array}{l}\text { ALK activating point } \\
\text { mutations }\end{array}$ & $\begin{array}{l}\text { L1198F and G1201E amino acid changes result in } \\
\text { constitutive ALK kinase activation }\end{array}$ & {$[92]$} \\
\hline Melanoma & ALK over-expression & $\begin{array}{l}6.9 \% \text { of acral melanomas were ALK positive, ALK } \\
\text { breakpoints suggest that translocations are present }\end{array}$ & {$[93]$} \\
\hline Rhabdomyosarcoma & ALK over-expression & $\begin{array}{l}45 \% \text { alveolar rhabdomyosarcomas examined were ALK } \\
\text { positive. High ALK mRNA expression is a negative } \\
\text { prognostic marker }\end{array}$ & {$[94-96]$} \\
\hline Retinoblastoma & Increased ALK mRNA & $\begin{array}{l}2 / 2 \text { retinoblastoma cell lines over-expressed ALK kinase } \\
\text { domain mRNA }\end{array}$ & {$[89]$} \\
\hline $\begin{array}{l}\text { Extramedullary } \\
\text { plasmacytoma }\end{array}$ & ALK over-expression & $\begin{array}{l}1 \text { case in } 46 \text { extramedullary plasmacytomas was ALK } \\
\text { positive by immunohistochemistry and FISH analysis }\end{array}$ & {$[97]$} \\
\hline
\end{tabular}

carried this open reading frame [8]. The EML4-ALK fusion results from an inversion in the short arm of chromosome two, fusing the N-terminal domain of EML4 to the intracellular kinase domain of ALK (3' gene region), resulting in a constitutively active ALK tryrosine kinase
[8].

ALK translocation positive lung tumors are often adenocarcinomas with a solid or acinar histology, and focal signet-ring cell features, that often occur in younger patients who are never or former/light smokers $[8,101-$ 
Table 2: A list of the ALK translocation found in NSCLC and some of the more common EML4-ALK fusion protein characteristics (modified from references 50,70,98,99).

\begin{tabular}{|l|l|l|l|}
\hline $\begin{array}{l}\text { ALK Fusion } \\
\text { Variant }\end{array}$ & $\begin{array}{l}\text { EML-ALK Translocation } \\
\text { Nomenclature }\end{array}$ & $\begin{array}{l}\text { Fusion Protein Characteristics (cell growth inhibition studies } \\
\text { were done in Ba/F3 cells expressing each EML4-ALK } \\
\text { variant) }\end{array}$ & $\begin{array}{l}\text { Frequency } \\
\text { in NSCLC }\end{array}$ \\
\hline E13;A20 & $\begin{array}{l}\text { E13;A20 (variant 1), E13;ins69 } \\
\text { A20 }\end{array}$ & $\begin{array}{l}\text { Cytoplasmic location, longer protein t1/2, cell growth } \\
\text { inhibition at moderate ALK inhibitor concentrations }\end{array}$ & $33 \%$ \\
\hline E6a/b;A20 & E6a/b;A20 (variants 3a/b) & $\begin{array}{l}\text { Cytoplasmic and nuclear locations, longer protein t1/2, cell } \\
\text { growth inhibition requires lower or moderate ALK inhibitor } \\
\text { concentrations (v3a and 3b, respectively) }\end{array}$ & $29 \%$ \\
\hline E20;A20 & $\begin{array}{l}\text { E20; A20 (variant 2), } \\
\text { E20;ins18A20 }\end{array}$ & $\begin{array}{l}\text { Cytoplasmic location, shorter protein t1/2, cell growth } \\
\text { inhibition at higher ALK inhibitor concentrations }\end{array}$ & $9 \%$ \\
\hline E14;A20 & $\begin{array}{l}\text { E14;ins11del49A20 (variant } \\
\text { 4'), E14;del12A20 (variant 7) }\end{array}$ & No data & $3 \%$ \\
\hline E18;A20 & E18; A20 (variant 5') & No data & $2 \%$ \\
\hline E15;A20 & E15 del19;del20A20 (variant 4) & No data & $2 \%$ \\
\hline E2;A20 & $\begin{array}{l}\text { E2; A20 \&E2;ins117A20 } \\
\text { (variant 5a/b) }\end{array}$ & No data & $2 \%$ \\
\hline E2;A20 & E17;ins68A20 & No data & $1 \%$ \\
\hline E6;A19 & Not defined & No data & $\begin{array}{l}\text { One } \\
\text { example }\end{array}$ \\
\hline KLC1-ALK & - & No data & Rare \\
\hline PTPN3-ALK & - & No data & Rare \\
\hline STRN-ALK & - & No data & Rare \\
\hline
\end{tabular}

104]. Although ALK fusion proteins can coexist with other lung cancer driver mutations, these molecular double-hits are rare [8,102-015]. This observation is not surprising as small interfering RNA silencing of the EML4-Alk fusion in cell lines inhibits cell growth more than $50 \%$, indicating that the EML4-ALK fusion, by itself, is sufficient as a malignancy driver mutation [72]. Due to the high world-wide lung cancer incidence ( 1.4 million deaths/year), ALK fusion positive lung cancers constitute the largest ALK positive patient population, comprising $\sim 70,000$ individuals [106]. Retrospective studies indicate that ALK fusion positivity was not a favorable prognostic factor in NSCLC prior to crizotinib based therapy [107]. Interestingly, Kim et al. [108] found ALK expression in $11.9 \%$ (8/67) of primary NSCLCs and 25.4\% (17/67) of metastatic lesions, indicating that metastatic progression can be associated changes in ALK expression. Last, advanced stage ALK-positive lung cancers may have a higher propensity for pleural and pericardial disease than lung cancers lacking ALK, KRAS, or EGFR mutations [109].

\section{Molecular Diagnostic Testing Methods for ALK- Fusions in NSCLC}

Since the introduction of crizotinib based chemotherapy, ALK mutation testing is now recommended for all NSCLCs [49]. There are several molecular
ALK mutation testing methods; the most common are immunohistochemistry (IHC), fluorescent in situ hybridization (FISH), and polymerase chain reaction based techniques (PCR). Here we will briefly review these methods and their relative advantages and disadvantages.

\section{FISH}

FISH analysis is considered the Gold Standard for ALK NSCLC mutation testing. In 2011 FDA approved the Abbot Vysis ALK Break Apart FISH Probe Kit for molecular diagnostic testing [110,111]. For the Vysis ALK procedure unstained tissue hybridized overnight with the ALK probe and is evaluated by fluorescence microscopy [102,110,112,113]. An ALK translocation is present when the ALK probe shows separated red and green fluorophores, or has loss of the green signal, in $15 \%$ or more of the cells examined. The green fluorophore binds the region 5' to ALK, while red binds to the 3' ALK kinase encoding region [110,111]. FISH analysis for EML4-ALK translocations can be challenging as: 1) it has a high cost, 2) its accurate interpretation requires expertise and experience, 3 ) it does not identify specific translocation types, and 4) often has a lengthy turn-around time $[102,110,112,113]$. The advantages of FISH are that it should detect all ALK rearrangements regardless of the fusion partner and is accurate and reliable.

\section{ALK IHC}

IHC readily identifies ALK in ALCL [113,114]. However, ALK protein levels in ALK-rearranged NSCLCs 
are comparatively low, making the ALK IHC detection methods used for ALCL inadequate [115]. Additionally, there is currently no standard protocol for using IHC to detect ALK in NSCLC ([115,116]. Antibodies used with some success have been D5F3 (Cell Signaling Technology, Danvers, MA, USA), 5A4 (Novocastra, Newcastle, UK), and ALK clone ZAL4 (Invitrogen, Carlsbad, CA, USA) $[73,83,86,88]$. Thunnissen et al. [116] pointed out that the current challenges in developing IHC for ALK detection in NSCLC are: 1) tissue preparation, 2) antibody choice, 3) signal enhancement systems, and 4) the optimal scoring system. The main advantages of IHC are: 1) low cost, 2) relative ease of implementation, 3) ease of interpretation by the general pathologist, 4) retention of histologic information, and 5) a short turn-around time. Currently the clinical application ALK IHC in NSCLC requires further analysis and validation [102,112,115-117].

\section{PCR}

PCR-based techniques can detect ALK expression in NSCLC, with protocols including reverse-transcriptase multiplexed PCR and analyses of the relative expression of the 5' and 3' portions of the ALK gene transcript by RTPCR [103,111,113,118,119].

\section{a. Reverse-Transcriptase PCR (RT-PRC)}

RT-PCR is a precise, sensitive, and reproducible technique that can detect EML4-ALK fusion transcripts. Additionally, the amplicons can be sequenced to identify the specific fusion variants [102,112,118]. In this procedure RNA is converted into cDNA by reverse transcriptase and the cDNA is PCR amplified with specific primers. Amplification requires primer sets specific for each translocation $[102,112,118]$. Commercial kits are available which usually have primers to most or all of the EML4-ALK fusions transcripts [103,111,113,118,119]. The amplicons are identified by a variety of methods, including sequencing, fluorescent probe degradation, electrophoresis, and NanoString nCounter capture technology [102,110,112,118,120].

\section{b. 5'-Rapid Amplification of cDNA Ends (RACE) Analysis}

All EML4-ALK fusion proteins carry the tyrosine kinase domain encoded by exon 20 and following distal 3' exons [69]. Wang et al. [91] used RACE analysis to quantify relative 5' and 3' ALK mRNA levels in NSCLCs. EML4-ALK mRNA was reverse transcribed into cDNA and different portions of the cDNA were amplified with primer sets specific to exons between E13-E18 and E22-E27. The E22-E27 domains where increased in $22.6 \%(40 / 177)$ of NSCLCs, ranging from 32.2 to $1573.7-$ fold increased expression when normalized to 5' ALK
mRNA expression. PCR ALK analysis in NSCLC: 1) is specific and sensitive, 2) can detect the EML4-ALK fusion transcript diluted in over 90\% wild-type RNA, and 3 ) is less expensive than FISH. The disadvantages of PCR are that: 1) it misses rare or novel translocations, 2) it can have contamination issues, and 3) RNA degradation/poor sample quality can prevent detection $[102,110,112,118,120]$.

\section{Other Methods of EML4-ALK Detection in NSCLC}

The EML4-ALK translocation has been detected by other less commonly employed molecular diagnostic methods, including:

\section{a. Next Generation Sequencing}

Peled et al. [121] used comprehensive genomic profiling by second generation sequencing to identify a complex ALK rearrangement in a lung adenocarcinoma previously found to be EML4-ALK negative by the Vysis FISH assay. Sequencing revealed a complex ALK rearrangement involving at least five different genomic loci. Sequencing the cDNA derived from the complex rearrangement did reveal the canonical EML4-ALK breakpoint. The authors hypothesized that the EML4 and ALK genes were separated by small rearrangements that prevented detection by FISH assay. The tumor was also ALK positive by IHC and the patient responded to crizotinib therapy. The authors suggested that second generation sequencing may be useful for NSCLC patients with a high likelihood of harboring driver mutations not detected by other methods.

\section{b. Exon Array Profiling for EML4-ALK Fusions}

Lin et al. [72] used exon array profiling (Affymetrix Human Exon 1.0 Arrays) to detect ALK rearrangements in breast, colorectal, and NSCLCs. Potential gene fusion candidates showed discordant 5' and 3' ALK transcript expression. Bioinformatic analysis revealed some tumors with differences between 5' and 3' ALK exon expression. Examination of these samples revealed EML4-ALK fusions in $2.4 \%$ of breast cancers (5/209), 2.4\% of colorectal (2/83), and $11.3 \%$ of NSCLCs (12/106). Thus, while a complex, expensive, and technically challenging method, exon array profiling detects EML4-ALK fusions.

\section{Alk-Inhibitor-Specific Therapy for NSCLC}

Following identification of the NSCLC EML4Alk fusion, a search for effective inhibitors with clinical applications began. The first clinically useful inhibitor PF- 
2341066 (crizotinib), is now in widespread use for treating EML4-ALK fusion positive NSCLC [94,95]. Crizotinib is an orally active aminopyridine derived small-molecule ATP-competitive inhibitor with dual actions on the c-Met and ALK kinases. It was first identified as an ALK inhibitor in cell-based selectivity assays, where it exerts a half maximal inhibitory concentration at $24 \mathrm{nmol} / \mathrm{L}$ in NPM-ALK positive ALCL cell lines and showed a nearly 20-fold increased selectivity for the ALK and MET kinases compared to a panel of more than 120 different kinases [95]. Crizotinib induces a $\mathrm{G}_{1} / \mathrm{S}$ phase cell cycle checkpoint and apoptosis in ALK-rearrangement positive, but not negative lymphoma cells. SCID-Beige mice xenografted subcutaneously with NPM-ALK positive cells treated with crizotinib at $100 \mathrm{mg} / \mathrm{kg} /$ day showed complete tumor regression within fifteen days, a significant tumor apoptosis induction, and a concomitant reduction in NPMALK phosphorylation and downstream signaling events [122-124].

The pharmacokinetics of crizotinib was first determined in humans in a Phase I clinical trial involving 167 patients who received an FDA-approved $250 \mathrm{mg}$ dose BID [125]. Peak drug plasma concentrations were achieved in 4-6 hours and steady-state concentrations were reached in fifteen days. Crizotinib was widely distributed to most tissues, but exhibited poor the bloodbrain barrier penetration. Its bioavailability was $43 \%$, with $91 \%$ being protein bound. The side effects of crizotinib were documented in a different Phase I study began in May, 2006. Thirty-seven patients with advanced stage tumors including colorectal, pancreatic, sarcoma, ALCL, and NSCLCs, were enrolled in dose-escalation testing. Crizotinib was administered under fasting conditions QD or BID on a continuous schedule to the patients in successive dose-escalating cohorts, at doses ranging from $50 \mathrm{mg}$ QD to $300 \mathrm{mg}$ BID. Dose-limiting toxicities included grade 3 increased alanine aminotransferase and grade 3 fatigue. The most common mild (grade 1 or 2 ) side effects were nausea, emesis, fatigue and diarrhea, reversed with drug cessation [126].

One of the first large trials examining the effectiveness of crizotinib was a multicenter trial of 82 ALK-rearrangement positive advanced NSCLCs screened from 1,500 patients with NSCLC. Most of the patients had received prior treatment. They were treated with a $250 \mathrm{mg}$ BID crizotinib dose in 28-day cycles. The patients were assessed for therapy response and adverse drug effects. The overall response rate was 57\% (47/82 patients) with 46 confirmed partial responses and one confirmed complete response. Twenty-seven (33\%) patients had stable disease. The estimated progression-free survival was $72 \%$ and the majority of the side effects were grade 1 or 2 . The authors concluded that crizotinib treatment resulted in tumor shrinkage in the majority of ALKpositive NSCLCs [127].

In a later study crizotinib treatment was compared to second line chemotherapy (docetaxel and pemetrexed) [128]. Three hundred and forty-seven patients with locally advanced or metastatic ALK-positive lung cancers who had received one prior treatment, were given $250 \mathrm{mg}$ oral crizotinib BID or intravenous chemotherapy with either pemetrexed or docetaxel every three weeks. The median progression-free survival was 7.7 months in the crizotinib group and three months in the pemetrexed or docetaxel-based treatment group. The response rate was $65 \%$ in the crizotinib group and $19.5 \%$ in the second line chemotherapy group. The patients receiving crizotinib reported a greater quality of life improvement and reduction in lung cancer symptoms compared to the chemotherapy group. The authors concluded that crizotinib is superior to standard chemotherapy for the treatment of advanced NSCLC with ALK-rearrangements. Possibly, NSCLCs carrying different EML-ALK translocations may respond to ALK inhibitor therapy with different sensitivities, patient response rates, and tumor burden reduction characteristics. Presently these studies have not been performed.

Crizotinib was Federal Food and Drug Administration (FDA) approved on August 26, 2011 the first FDA-approved NSCLC personalized therapy in which treatment is determined by clinically validated ALK testing [49,111,129]. Approval came five years after the initial clinical trails, with accelerated approval based on the surrogate endpoint of overall response rate. Post-marketing requirements include in vitro studies to evaluating its effects on the CYP2B and CYP2C enzymes and further clinical trials further evaluate its side-effects [130]. The European Medical Agency (EMA) approved crizotinib on 7/19/2012 following further analysis of randomized data [131]. FDA and EMA drug approval guidelines are similar in their relative efficacy of drug analysis, risk evaluation, and analysis of the drug once it's entered clinical use [132].

\section{Molecular Mechanisms of Crizotinib Resistance}

Although ALK-positive tumors generally respond to critzotinib therapy, most patients relapse due to the development of resistance. In two small studies consisting of 12 and 18 ALK-positive, critzotinib-treated relapsed individuals, the average time of relapse was 8.9 and 10.5 months, with ranges from 3.5 to 21.1 , and 4 to 34 months, respectively [99,133]. Resistance mechanisms are usually alterations in the EML-ALK fusion sequence, increased rearranged ALK gene copy number, or the activation of other driver mutations $[99,134]$. In some cases two or more resistance mechanisms are found in the same tumor [134]. Interestingly, in these studies only 36 and $28 \%$ of the critzotinib resistance was due to secondary rearranged ALK gene mutations not found in the tumor at the initial diagnosis $[99,134$, respectively]. Most resistance mechanisms involve the increased activity of other driver 
Table 3: Different mechanisms of crizotinib resistance. "pm" denotes a point mutation.

\begin{tabular}{|c|c|c|}
\hline $\begin{array}{l}\text { Mechanism of Crizotinib } \\
\text { Resistance }\end{array}$ & Comment(s) & References \\
\hline G1269A EML-ALKpm & Gly $\rightarrow$ Ala reduces crizotinib binding ATP-binding pocket by steric hindrance & [99] \\
\hline L1196M EML-ALKpm & Gatekeeper residue mutation blocks crizotinib binding & $\begin{array}{l}{[99,133,} \\
134]\end{array}$ \\
\hline C1156Y EML-ALKpm & Alters ALK crizotinib binding cavity, reducing crizotinib-protein interactions & $\begin{array}{l}{[99,133} \\
134]\end{array}$ \\
\hline S1206Y EML-ALKpm & $\begin{array}{l}\text { Lowers crizotinib-protein affinity by eliminating two H-bonds between crizotinib } \\
\text { and the ALK binding site }\end{array}$ & $\begin{array}{l}{[133,134,} \\
135]\end{array}$ \\
\hline L1152R EML-ALKpm & Mutation resistant to crizotinib and the structurally unrelated compound TAE684 & [136] \\
\hline G1202R EML-ALKpm & $\begin{array}{l}\text { A mutation-specific strong H-bond pulls crizotinib out of the position found in the } \\
\text { non-crizotinib resistant EML-ALK fusion gene }\end{array}$ & {$[133,135]$} \\
\hline 1151Tins & Thr insertion is predicted to alter ATP binding to ALK & [133] \\
\hline ALK Copy Number Gain & $\begin{array}{l}\text { Two cases; one with and one without an ALK mutation, 4-5-fold increased } \\
\text { expression }\end{array}$ & [99] \\
\hline EGFR Alterations & $\begin{array}{l}\text { L585R mutation in one case, other cases often show in EGFR and EGFR } \\
\text { amplification }\end{array}$ & $\begin{array}{l}{[99,133,} \\
136]\end{array}$ \\
\hline KRAS Mutations & G12C and G12V activating KRAS mutations & [99] \\
\hline $\mathrm{c}-\mathrm{Kit}$ & 5-fold c-KIT amplification & [133] \\
\hline Increased Autophagy & $\begin{array}{l}\text { Increased autophagy involves Akt/mTOR signaling, autophagy inhibitors can } \\
\text { restore crizotinib sensitivity in cell lines }\end{array}$ & {$[137]$} \\
\hline Unknown & Crizotinib resistance by increased expression of unknown oncogenic drivers & [133] \\
\hline
\end{tabular}

mutations $[99,134]$. Examples of some of the known mechanisms of critzotinib resistance are summarized in Table 3 (Table 3) [99-133-137]. Comparison of the initial diagnostic tumor biopsy to the resistant tumor often, but not always, revealed that the resistance mechanism was not present in the diagnostic biopsy [99,134]. Doebele et al. [99] identified two initially ALK-positive tumors which became negative following critzotinib therapy. Several studies demonstrated that critzotinib resistant cells had increased markers of cell growth and division compared to critzotinib sensitive cells, including increased Ki-67 and phosphorylated EGFR, ALK, ERK, and STAT3 $[99,134,135]$. Interestingly, increased autophagy may also play a role in critzotinib resistance [137].

\section{Second Generation ALK Inhibitors}

Since resistance occurs in most critzotinib-treated patients, efforts have been made to develop ALK inhibitors which overcome this resistance. Phase I studies have been completed on several of these drugs and Phase 11 and III studies are ongoing [138-145]. One drug, LDK378 (Novartis), has received breakthrough FDA approval [146].

\section{AP26113}

AP26113 (Ariad) is an orally-active TKI that inhibits native and rearranged EML-ALK fusion proteins and the T790M (but not native) EGFR protein [138]. In vitro studies revealed that AP26113 inhibited the native and F1174C, L1196M, S1206R, E1210K, F1245C, and G1269S EML-ALK fusions at IC50's of 14-269 nM [145]. In the BaF3 xenograft model AP26113 induced tumor regression in cells expressing the native, G1269S, and L1196M fusion proteins at 25, 50, and $50 \mathrm{mg} / \mathrm{kg}$, respectively [145]. In one study of 15 patients, 8 with NSCLC (4 ALK+ critzotinib-resistant and 4 with TKIrefectory EGFR mutations) were treated with AP26113. No serious adverse events were seen at $120 \mathrm{mg}$ /day [138]. Partial responses were seen in 4 of 4 ALK-positive patients in the Phase II expansion study [138]. Further Phase II studies on other molecular cohorts, such as individuals with ALK-positive critzotinib-resistant NSCLCs and T790M EGFR-positive NSCLCs are being planned [144].

\section{LDK378}

LDK378 is an orally active ALK inhibitor which induced EML-ALK positive tumor regression in xenograft models and exhibited a minimally 70 -fold greater ALK inhibition when compared to other kinases [141]. In a Phase I study of 59 patients, 50 of which had ALKpositive NSCLC, of which 37 of these had received critzotinib therapy and 26 of which had progressed on this therapy, $81 \%$ of this group $(21 / 26)$ responded to $>400$ mg/day LDK378 [139]. The maximum tolerated LDK378 dose was $750 \mathrm{mg} /$ day, with the side effects being diarrhea, vomiting, nausea, dehydration, and ALT elevation [141]. Phase II trails are underway with this compound [146]. 


\section{RO5424802}

RO5424802 (Roche) is an orally active ALKspecific kinase inhibitor which binds the ALK binding domain, inhibiting ALK at $\mathrm{nM}$ concentrations $[142,143]$. RO5424802 treatment inhibited the growth of cells expressing the native, and L1196M and C1156Y EML-ALK mutants and inhibited ALK and STAT3 phosphorylation, and lowered the levels of the STAT3regulated proteins BCL3 and NNMT $[142,143]$. In a Phase I and II dose escalation study 70 Japanese patients with ALk-positive NSCLCs were treated with RO5424802 [140]. In Phase I of this study 24 patients received 20-300 mg RO5424802 twice daily. No dose-limiting toxicities or grade 4 adverse events were seen at $300 \mathrm{mg}$ twice daily. In Phase II of this study 46 patients were treated with this dose and $43(93.5 \%)$ of patients achieved an objective response, including 2 complete responses $(4.3 \%)$ and $41(89.1 \%)$ partial responses [140]. Serious side effects occurred in 5 patients (11\%) which included decreased neutrophils and increased blood creatine phosphokinase [140]. Interestingly, cell lines expressing the EML-ALK fusion exposed in vitro to RO5424802 develop resistanceconferring mutations, suggesting that RO5424802resistant tumors may appear in treated individuals [147].

\section{HSP90 Inhibitors and EML-ALK Positive Lung Cancer}

Heat shock proteins (HSP) function as part of normal cellular stress responses that protect cells from lethal damage and in cancer their increased expression contributes to increased tumor growth, metastasis, and a worse prognosis $[148,149]$. HSP90 has been extensively studied in cancer and is required for the correct folding and stability of multiple oncogenic proteins, including EMLALK [150]. Inhibition of normal HSP90 function induces fusion protein misfolding and subsequent degradation by the proteasome system $[150,151]$. Several HSP90 inhibitors, AUY922, IPI 504, and Ganetespib (Norvartis, Infinity, and Synta Pharmaceuticals, respectively) have shown some efficacy suppressing the growth of EMLALK fusion expressing cell lines and in treating ALKpositive NSCLC patients in Phase II trials [151-155].

\section{CONCLUSION}

EML4-ALK fusions are found in a low percentage of NSCLCs [8,9]. However, since lung cancer is a common malignancy, an estimated 70,000 cases of ALK positive NSCLC occur world-wide each year, comprising the most common ALK-positive human malignancy [1$5,8,9,106]$. Currently crizotinib is the "drug of choice" for the NSCLCs $[49,11,129]$. The clinical response rates with crizotinib and the newer ALK inhibitors are roughly $30 \%$ more effective than conventional chemotherapeutic treatments [122-128,138-145]. Thus, although ALKrearrangement targeted treatments offer a better treatment regimen, advanced ALK-rearranged NSCLC still carries a poor prognosis. Several improvements that are likely to be implemented to improve targeted ALK-positive NSCLC include:

1.Implementation of low cost, reliable, and sensitive ALK detections methods.

ALK detection by FISH is an expensive, slow, and cumbersome detection method $[102,110,112,113]$. ALK detection by IHC will likely replace FISH, as it is easier to implement, costs less, requires less expertise to perform, and has a rapid turn-around time [116,156]. It's also likely that second and third generation DNA sequencing will become more common in molecular diagnostics, as the cost of sequencing continues to fall [157]. Whole-exon or whole-genome sequencing could identify most or all changes NSCLC DNA. As the number of "actionable" (treatable) mutations increases, sequencing would be a more efficient and cost-effective molecular testing method than multiple tests analyzing a single gene alteration.

\section{The development of new inhibitors in lung cancer treatment.}

New ALK inhibitors which overcome crizotinib resistance will soon enter clinical use. [138-146]. Additionally, KRAS mutations are found in $15-30 \%$ of lung cancers and are presently undruggable, although KRAS inhibitor are being developed [38,42]. New driver mutation specific inhibitors would significantly improve lung cancer treatment options.

\section{The use of multiple inhibitors and/or multi- targeted inhibitors.}

Katayama et al. [133] found that one crizotinib resistant tumor which carried three different molecular resistance mechanisms. Molecular diagnostics defining the specific constellation of molecular alterations characterizing each NSCLC (especially for resistant tumors), could allow a specific directed cancer treatment with the least amount of damage to non-neoplastic tissue $[158,159]$.

Taken together, these developments would significantly increase NSCLC patient survival while lowering treatment-associated morbidity.

\section{ACKNOWLEDGMENTS}

We would like to thank Lisa LaChance for proof reading and help with organizing this manuscript. 


\section{REFERENCES}

1. Ferlay J, Shin HR, Bray F, Forman D, Mathers C, Parkin DM. Estimates of worldwide burden of cancer in 2008: GLOBOCAN 2008. Int J Cancer. 2010;127:2893-917.

2. Ettinger DS, Akerley W, Bepler G, et al. NCCN Non-Small Cell Lung Cancer Panel Members. Non-small cell lung cancer. J Natl Compr Canc Netw. 2010;8:740-801.

3. Hsiao SH, Chung CL, Lee CM, et al. Suitability of Computed Tomography-Guided Biopsy Specimens for Subtyping and Genotyping of Non-Small-Cell Lung Cancer. Clin Lung Cancer. 2013:S1525-7304(13)00130-7.

4. Alberg AJ, Brock MV, Ford JG, Samet JM, Spivack SD. Epidemiology of lung cancer: Diagnosis and management of lung cancer, 3rd ed: American College of Chest Physicians evidence-based clinical practice guidelines. Chest. 2013;143(5 Suppl):e1S-29S.

5. SEER Cancer Statistics Review, 1973-2008. Washington DC: US National Institutes of Health. National Cancer Institute.

6. Vogelstein B, Papadopoulos N, Velculescu VE, Zhou S, Diaz LA Jr, Kinzler KW. Cancer genome landscapes. Science. 2013;339:1546-58.

7. Govindan R, Ding L, Griffith M, Subramanian J, et al. Genomic landscape of non-small cell lung cancer in smokers and never-smokers. Cell. 2012;150:1121-34.

8. Soda M, Choi YL, Enomoto M, Takada S, et al. Identification of the transforming EML4-ALK fusion gene in non-small-cell lung cancer. Nature. 2007;448:561-6.

9. Rikova K, Guo A, Zeng Q, et al. Global survey of phosphotyrosine signaling identifies oncogenic kinases in lung cancer. Cell. 2007;131:1190-203.

10. Samuels Y, Wang Z, Bardelli A, et al. High frequency of mutations of the PIK3CA gene in human cancers. Science 2004;304:554.

11. Heinmoller P, Gross C, Beyser K, et al. HER2 status in nonsmall cell lung cancer: results from patient screening for enrollment to a phase II study of herceptin. Clin Cancer Res 2003; 9:5238-43.

12. Stephens P, Hunter C, Bignell G, et al. Lung cancer: intragenic ERBB2 kinase mutations in tumours. Nature 2004; 431: 525-26.

13. Ding L, Getz G, Wheeler DA, et al. Somatic mutations affect key pathways in lung adenocarcinoma. Nature 2008;455:1069-75.

14. Malanga D, Scrima M, De Marco C, et al. Activating E17K mutation in the gene encoding the protein kinase AKT1 in a subset of squamous cell carcinoma of the lung. Cell Cycle 2008;7:665-69.

15. Davies H, Bignell GR, Cox C, et al. Mutations of the BRAF gene in human cancer. Nature 2002;417:949-54.

16. Sasaki H, Kawano O, Endo K, et al. Uncommon V599E BRAF mutations in Japanese patients with lung cancer. J Surg Res 2006;133:203-06.
17. Naoki K, Chen TH, Richards WG, Sugarbaker DJ, Meyerson M. Missense mutations of the BRAF gene in human lung adenocarcinoma. Cancer Res 2002;62:7001-03.

18. Marks JL, Gong Y, Chitale D, et al. Novel MEK1 mutation identified by mutational analysis of epidermal growth factor receptor signaling pathway genes in lung adenocarcinoma. Cancer Res 2008;68:5524-28.

19. Onozato R, Kosaka T, Kuwano H, Sekido Y, Yatabe Y, Mitsudomi T. Activation of MET by gene amplifi cation or by splice mutations deleting the juxtamembrane domain in primary resected lung cancers. J Thorac Oncol 2009;4:5-11.

20. Cappuzzo F, Marchetti A, Skokan M, et al. Increased MET gene copy number negatively aff ects survival of surgically resected non-small-cell lung cancer patients. J Clin Oncol 2009;27:1667-74.

21. Beau-Faller M, Ruppert AM, Voegeli AC, et al. MET gene copy number in non-small cell lung cancer: molecular analysis in a targeted tyrosine kinase inhibitor naive cohort. J Thorac Oncol 2008;3:331-39.

22. Cancer Genome Atlas Research Network. Comprehensive genomic characterization of squamous cell lung cancers. Nature. 2012;489:519-25.

23. Forbes SA, Bindal N, Bamford S, Cole C, Kok CY, Beare D, et al. COSMIC: mining complete cancer genomes in the Catalogue of Somatic Mutations in Cancer. Nucleic Acids Res 2011;39:D945-50. P

24. Kohno T, Takahashi M, Manda R, Yokota J. Inactivation of the PTEN/MMAC1/TEP1 gene in human lung cancers. Genes Chromosomes Cancer 1998;22152-6.

25. Marsit CJ, Zheng S, Aldape K, et al. PTEN expression in non-small-cell lung cancer: evaluating its relation to tumor characteristics, allelic loss, and epigenetic alteration. Hum Pathol 2005;36768-76.

26. Soria JC, Lee HY, Lee JI, et al. Lack of PTEN expression in non-small cell lung cancer could be related to promoter methylation. Clin Cancer Res 2002;81178-84.

27. Jin G, Kim MJ, Jeon HS, et al. PTEN mutations and relationship to EGFR, ERBB2, KRAS, and TP53 mutations in non-small cell lung cancers. Lung Cancer 2010;69:27983.

28. Bass AJ, Watanabe $\mathrm{H}$, Mermel $\mathrm{CH}$, et al. SOX2 is an amplified lineage-survival oncogene in lung and esophageal squamous cell carcinomas. Nat Genet 2009;41:1238-42.

29. Dutt A, Ramos AH, Hammerman PS, et al. Inhibitorsensitive FGFR1 amplification in human non-small cell lung cancer. PLoS ONE 2011;6:e20351.

30. Hammerman PS, Sos ML, Ramos AH, et al. Mutations in the DDR2 kinase gene identify a novel therapeutic target in squamous cell lung cancer. Cancer Discov 2011;1:78-89.

31. Matsumoto S, Iwakawa R, Takahashi K, et al. Prevalence and specificity of LKB1 genetic alterations in lung cancers. Oncogene 2007;26:5911-8.

32. Hussenet T, Dali S, Exinger J, et al. SOX2 is an oncogene activated by recurrent $3 q 26.3$ amplifications in human lung 
squamous cell carcinomas. PLoS ONE 2010;5:e8960.

33. Weiss J, Sos ML, Seidel D, Peifer M, Zander T, Heuckmann JM, et al. Frequent and focal FGFR1 amplification associates with therapeutically tractable FGFR1 dependency in squamous cell lung cancer. Sci Transl Med 2010;2:62ra93.

34. Bass AJ, Watanabe $\mathrm{H}$, Mermel $\mathrm{CH}$, et al. SOX2 is an amplified lineage-survival oncogene in lung and esophageal squamous cell carcinomas. Nat Genet 2009;41:1238-42.

35. Hammerman PS, Hayes DN, Wilkerson MD, et al. Comprehensive genomic characterization of squamous cell lung cancers. Nature 2012;489:519-525.

36. Rikova K, Guo A, Zeng Q, et al. Global survey of phosphotyrosine signaling identifies oncogenic kinases in lung cancer. Cell 2007;131:1190-203.

37. Takeuchi K, Soda M, Togashi Y, et al. RET, ROS1 and ALK fusions in lung cancer. Nat Med 2012;18:378-81. $\mathrm{http}: / /$ clincancerres.aacrjournals.org/external-ref?access num $=10.1038 / \mathrm{nm} .2658 \&$ link_type $=$ DOI

38. Planchard D. Identification of driver mutations in lung cancer: first step in personalized cancer. Target Oncol. 2013;8:3-14.

39. Köhler J, Schuler M. Afatinib, Erlotinib and Gefitinib in the First-Line Therapy of EGFR Mutation-Positive Lung Adenocarcinoma: A Review. Onkologie. 2013;36:510-8.

40. Ohashi K, Sequist LV, Arcila ME, et al. Lung cancers with acquired resistance to EGFR inhibitors occasionally harbor BRAF gene mutations but lack mutations in KRAS, NRAS, or MEK1. Proc Natl Acad Sci U S A. 2012;109:E2127-33.

41. Burgeiro A, Mollinedo F, Oliveira PJ. Ipilimumab and vemurafenib: two different routes for targeting melanoma. Curr Cancer Drug Targets. 2013;13:879-94.

42. Zimmermann G, Papke B, Ismail S, et al. Small molecule inhibition of the KRAS-PDE $\delta$ interaction impairs oncogenic KRAS signalling. Nature. 2013;497:638-42.

43. Maemondo M, Inoue A, Kobayashi K, Sugawara S, Oizumi $\mathrm{S}$, Isobe $\mathrm{H}$, Gemma A, Harada M, Yoshizawa H, Kinoshita I, et al. North-East Japan Study Group. Gefitinib or chemotherapy for non-small-cell lung cancer with mutated EGFR. N Engl J Med. 2010;362:2380-8.

44. Shaw AT, Kim DW, Nakagawa K, Seto T, et al. Crizotinib versus chemotherapy in advanced ALK-positive lung cancer. N Engl J Med. 2013;368:2385-94.

45. Shepherd FA, Rodrigues Pereira J, Ciuleanu T, Tan EH, Hirsh V, Thongprasert S, Campos D, Maoleekoonpiroj $\mathrm{S}$, Smylie M, et al. National Cancer Institute of Canada Clinical Trials Group. Erlotinib in previously treated nonsmall-cell lung cancer. N Engl J Med. 2005;353:123-32.

46. Jänne PA, Gurubhagavatula S, Yeap BY, et al. Outcomes of patients with advanced non-small cell lung cancer treated with gefitinib (ZD1839, "Iressa") on an expanded access study. Lung Cancer. 2004;44:221-30.

47. Jackman DM, Miller VA, Cioffredi LA, et al. Impact of epidermal growth factor receptor and KRAS mutations on clinical outcomes in previously untreated non-small cell lung cancer patients: Results of an online tumor registry of clinical trials. Clin Cancer Res. 2009;15:5267-5273.

48. West H, Lilenbaum R, Harpole D, et al. Molecular analysisbased treatment strategies for the management of non-small cell lung cancer. J Thorac Oncol. 2009;4:s1029-s39.

49. Lindeman NI, Cagle PT, Beasley MB, et al. Molecular testing guideline for selection of lung cancer patients for EGFR and ALK tyrosine kinase inhibitors: guideline from the College of American Pathologists, International Association for the Study of Lung Cancer, and Association for Molecular Pathology. J Mol Diagn. 2013;15:415-53.

50. Hallberg B, Palmer RH. Mechanistic insight into ALK receptor tyrosine kinase in human cancer biology. Nat Rev Cancer 2013;13:685-700.

51. Bilsland, J. G. et al. Behavioral and neurochemical alterations in mice deficient in anaplastic lymphoma kinase suggest therapeutic potential for psychiatric indications. Neuropsychopharmacology 2008;33:685-700.

52. Hurley SP, Clary D, Copie V, Lefcort F. Anaplastic lymphoma kinase is dynamically expressed on subsets of motor neurons and in the peripheral nervous system. J. Comp. Neurol. 2006:495;202-12.

53. Vernersson, E. et al. Characterization of the expression of the ALK receptor tyrosine kinase in mice. Gene Expr. Patterns 2006:6;448-61.

54. Weiss, J. B. et al. Anaplastic lymphoma kinase and leukocyte tyrosine kinase: functions and genetic interactions in learning, memory and adult neurogenesis. Pharmacol. Biochem. Behav. 2012:100;566-74.

55. Iwahara, T. et al. Molecular characterization of ALK, a receptor tyrosine kinase expressed specifically in the nervous system. Oncogene 1997:14;439-49.

56. Ning $H$, Mitsui $H$, Wang CQ, Suárez-Fariñas $M$, et al. Identification of anaplastic lymphoma kinase as a potential therapeutic target in Basal Cell Carcinoma. Oncotarget. 2013 in press.

57. Weiss JB, Xue C, Benice T, Xue L, Morris SW, Raber J. Anaplastic lymphoma kinase and leukocyte tyrosine kinase: functions and genetic interactions in learning, memory and adult neurogenesis. Pharmacol Biochem Behav. 2012;100:566-74.

58. Reiner DJ, Ailion M, Thomas JH, Meyer BJ. C. elegans anaplastic lymphoma kinase ortholog SCD-2 controls dauer formation by modulating TGF-beta signaling. Curr Biol. 2008;18:1101-9.

59. Ishihara $\mathrm{T}$, Iino $\mathrm{Y}$, Mohri A, et al. HEN-1, a secretory protein with an LDL receptor motif, regulates sensory integration and learning in Caenorhabditis elegans. Cell. 2002;109:639-49.

60. Stoica GE, Kuo A, Aigner I, et al. Identification of anaplastic lymphoma kinase as a receptor for the growth factor pleiotrophin. J. Biol. Chem. 2001:276;16772-9.

61. Stoica GE, Kuo A, Powers C, et al. Midkine binds 
to anaplastic lymphoma kinase (ALK) and acts as a growth factor for different cell types. J. Biol. Chem. 2002:277;35990-8.

62. Mathivet T1, Mazot P, Vigny M. In contrast to agonist monoclonal antibodies, both C-terminal truncated form and full length form of Pleiotrophin failed to activate vertebrate ALK (anaplastic lymphoma kinase)? Cell Signal. 2007;19:2434-43.

63. Moog-Lutz C1, Degoutin J, Gouzi JY, et al. Activation and inhibition of anaplastic lymphoma kinase receptor tyrosine kinase by monoclonal antibodies and absence of agonist activity of pleiotrophin. J Biol Chem. 2005;280:26039-48.

64. Mourali J1, Bénard A, Lourenço FC, et al. Anaplastic lymphoma kinase is a dependence receptor whose proapoptotic functions are activated by caspase cleavage. Mol Cell Biol. 2006;26:6209-22.

65. Motegi A1, Fujimoto J, Kotani M, Sakuraba H, Yamamoto T. ALK receptor tyrosine kinase promotes cell growth and neurite outgrowth. J Cell Sci. 2004;117:3319-29.

66. Morris SW, Kirstein MN, Valentine MB, Dittmer KG, Shapiro DN, Saltman DL, Look AT. Fusion of a kinase gene, ALK, to a nucleolar protein gene, NPM, in nonHodgkin's lymphoma. Science. 1994;263:1281-4.

67. Delsol G, Ralfkiaer E, Stein H, Wright D, Jaffe ES. Anaplastic large cell lymphoma: primary systemic (T/null cell type). In: Jaffe ES, Harris NL, Stein H, eds. World Health Organization (WHO) Classification of Tumours: Pathology and Genetics of Tumours of Haematopoietic and Lymphoid Tissues. Lyon, France: IARC Press; 2001:230-5.

68. Stein H, Foss HD, Durkop H, et al. CD30(+) anaplastic large cell lymphoma: a review of its histopathologic, genetic, and clinical features. Blood. 2000;96:3681-95.

69. Pulford K, Lamant L, Espinos E, et al. The emerging normal and disease-related roles of anaplastic lymphoma kinase. Cell Mol Life Sci. 2004;61:2939-53.

70. Heuckmann JM, Balke-Want H, Malchers F, et al. Differential protein stability and ALK inhibitor sensitivity of EML4-ALK fusion variants. Clin Cancer Res. 2012;18:4682-90.

71. Takeuchi K, Choi YL, Togashi Y, et al. KIF5BALK, a novel fusion oncokinase identified by an immunohistochemistry-based diagnostic system for ALKpositive lung cancer. Clin Cancer Res. 2009;15:3143-9.

72. Lin E, Li L, Guan Y, Soriano R, et al. Exon array profiling detects EML4-ALK fusion in breast, colorectal, and nonsmall cell lung cancers. Mol Cancer Res. 2009;7:1466-76.

73. Robertson FM, Petricoin Iii EF, Van Laere SJ, et al. Presence of anaplastic lymphoma kinase in inflammatory breast cancer. Springerplus. 2013;2:497.

74. Lamant L, Pulford K, Bischof D, et al. Expression of the ALK tyrosine kinase gene in neuroblastoma. Am J Pathol. 2000;156:1711-21.

75. Wang M, Zhou C, Sun Q, Cai R, Li Y, Wang D, Gong L. ALK amplification and protein expression predict inferior prognosis in neuroblastomas. Exp Mol Pathol. 2013;95:12430.

76. Mossé YP, Laudenslager M, Longo L, et al. Identification of ALK as a major familial neuroblastoma predisposition gene. Nature 2008;455:930-5.

77. Cook JR, Dehner LP, Collins MH, et al. Anaplastic lymphoma kinase (ALK) expression in the inflammatory myofibroblastic tumor: a comparative immunohistochemical study. Am J Surg Pathol 2001;25:1364-71.

78. Gleason BC, Hornick JL. Inflammatory myofibroblastic tumours: where are we now? J Clin Pathol 2008; 61:428-37.

79. Coffin CM, Patel A, Perkins S, Elenitoba-Johnson KS, Perlman E, Griffin CA. ALK1 and p80 expression and chromosomal rearrangements involving $2 \mathrm{p} 23$ in inflammatory myofibroblastic tumor. Mod Pathol 2001;14:569-76.

80. Gascoyne RD, Lamant L, Martin-Subero JI, et al. ALKpositive diffuse large B-cell lymphoma is associated with Clathrin-ALK rearrangements: report of 6 cases. Blood 2003; 102:2568-73.

81. Laurent C, Do C, Gascoyne RD, Lamant L, et al. Anaplastic lymphoma kinase-positive diffuse large B-cell lymphoma: a rare clinicopathologic entity with poor prognosis. J Clin Oncol 2009;27:4211-6.

82. Powers C, Aigner A, Stoica GE, McDonnell K, and Wellstein A. Pleiotrophin signaling through anaplastic lymphoma kinase is rate-limiting for glioblastoma growth. J Biol Chem 2002;277:14153-8.

83. Grzelinski M, Steinberg F, Martens T, Czubayko F, Lamszus K, Aigner A. Enhanced antitumorigenic effects in glioblastoma ondouble targeting of pleiotrophin and its receptor ALK. Neoplasia 2009;11:145-56

84. Debelenko LV, Raimondi SC, Daw N, et al. Renal cell carcinoma with novel VCL-ALK fusion: new representative of ALK-associated tumor spectrum. Mod Pathol 2011;24:430-42.

85. Mariño-Enríquez A, Ou WB, Weldon CB, Fletcher JA, Pérez-Atayde AR. ALK rearrangement in sickle cell trait-associated renal medul $\neg$ lary carcinoma. Genes Chromosomes Cancer 2011;50:146-53.

86. Sukov WR, Hodge JC, Lohse CM, et al. ALK alterations in adult re $\neg$ nal cell carcinoma: frequency, clinicopathologic features and out $\neg$ come in a large series of consecutively treated patients. Mod Pathol 2012;25:1516-25.

87. Sugawara E, Togashi Y, Kuroda N, et al. Identification of anaplastic lymphoma kinase fusions in renal cancer: large-scale immunohis $\neg$ tochemical screening by the intercalated antibody-enhanced poly $\neg$ mer method. Cancer 2012;118:4427-36.

88. Du XL, Hu H, Lin DC, Xia SH, et al. Proteomic profiling of proteins dysregulted in Chinese esophageal squamous cell carcinoma. J Mol Med. 2007;85:863-75.

89. Dirks WG, Fahnrich S, Lis $\mathrm{Y}$, et al. Expression and functional analysis of the anaplastic lymphoma kinase 
(ALK) gene in tumor cell lines. Int J Cancer 2002;100:4956.

90. Li XQ, Hisaoka M, Shi DR, et al. Expression of anaplastic lymphoma kinase in soft tissue tumors an immunohistochemical and molecular study of 249 cases. Hum Pathol 2004;35:711-21.

91. Ren H, Tan ZP, Zhu X, et al. Identification of anaplastic lymphoma kinase as a potential therapeutic target in ovarian cancer. Cancer Res. 2012;72:3312-23.

92. Murugan AK, Xing M. Anaplastic thyroid cancers harbor novel oncogenic mutations of the ALK gene. Cancer Res. 2011;71:4403-11.

93. Niu HT, Zhou QM, Wang F, et al. Identification of anaplastic lymphoma kinase break points and oncogenic mutation profiles in acral/mucosal melanomas. Pigment Cell Melanoma Res. 2013;26:646-53.

94. Pillay K, Govender D, Chetty R. ALK protein expression in rhabdomyosarcomas. Histopathology. 2002;41:461-7.

95. Corao DA, Biegel JA, Coffin CM, et al. ALK expression in rhabdomyosarcomas: correlation with histologic subtype and fusion status. Pediatr Dev Pathol. 2009;12:275-83.

96. Bonvini P, Zin A, Alaggio R, Pawel B, Bisogno G, Rosolen A. High ALK mRNA expression has a negative prognostic significance in rhabdomyosarcoma. Br J Cancer. 2013, in press.

97. Wang WY, Gu L, Liu WP, Li GD, Liu HJ, Ma ZG. ALKpositive extramedullary plasmacytoma with expression of the CLTC-ALK fusion transcript. Pathol Res Pract 2011;207:587-91.

98. Sasaki T, Rodig SJ, Chirieac LR, Jänne PA. The biology and treatment of EML4-ALK non-small cell lung cancer. Eur J Cancer. 2010;46:1773-80.

99. Doebele RC1, Pilling AB, Aisner DL, et al. Mechanisms of resistance to crizotinib in patients with ALK gene rearranged non-small cell lung cancer. Clin Cancer Res. 2012;18:1472-82.

100. Schönherr C, Ruuth K, Eriksson T, et al. The neuroblastoma ALK(I1250T) mutation is a kinase-dead RTK in vitro and in vivo. Transl Oncol. 2011;4:258-65.

101. Rodig SJ, Mino-Kenudson M, Dacic S, et al. Unique clinicopathologic features characterize ALK-rearranged lung adenocarcinoma in the western population. Clin Cancer Res. 2009;15:5216-23.

102. Li Y, Pan Y, Wang R, Sun Y, et al. ALK-rearranged lung cancer in Chinese: a comprehensive assessment of clinicopathology, IHC, FISH and RT-PCR. PLoS One. 2013;8:e69016.

103. Shaw AT, Yeap BY, Mino-Kenudson M, et al. Clinical features and outcome of patients with non-small-cell lung cancer who harbor EML4-ALK. J Clin Oncol. 2009;27:4247-53.

104. Inamura K, Takeuchi K, Togashi Y, et al. EML4-ALK fusion is linked to histological characteristics in a subset of lung cancers. J Thorac Oncol. 2008;3:13-17.
105. Shaozhang Z, Xiaomei L, Aiping Z, et al. Detection of EML4-ALK fusion genes in non-small cell lung cancer patients with clinical features associated with EGFR mutations. Genes Chromosomes Cancer. 2012;51:925-32.

106. Jemal, A. Clegg LX, Ward E, et al. Annual report to the nation on the status of cancer, 1975-2001, with a special feature regarding survival. Cancer 2004;101;3-27.

107. Shaw, AT. et al. Impact of crizotinib on survival in patients with advanced, ALK-positive NSCLC compared with historical controls. J. Clin. Oncol. 2001, 29, Abstr. 7507.

108. Kim H, Xu X, Yoo SB, et al. Discordance between anaplastic lymphoma kinase status in primary non-smallcell lung cancers and their corresponding metastases. Histopathology. 2013;62:305-14.

109. Doebele RC, Lu X, Sumey C, et al. Oncogene status predicts patterns of metastatic spread in treatment-naive nonsmall cell lung cancer. Cancer. 2012;118:4502-11.

110. Lira ME, Kim TM, Huang D, et al. Multiplexed gene expression and fusion transcript analysis to detect ALK fusions in lung cancer. J Mol Diagn. 2013:15:51-61.

111. http:/www.abbott.com/news-media/press-releases/2011aug26.htm

112. Wu YC, Chang IC, Wang CL, et al. Comparison of IHC, FISH and RT-PCR methods for detection of ALK rearrangements in 312 non-small cell lung cancer patients in Taiwan. PLoS One. 2013;8:e70839.

113. Lamant L, Meggetto F, al Saati T, et al. High incidence of the $\mathrm{t}(2 ; 5)(\mathrm{p} 23 ; \mathrm{q} 35)$ translocation in anaplastic large cell lymphoma and its lack of detection in Hodgkin's disease. Comparison of cytogenetic analysis, reverse transcriptasepolymerase chain reaction, and P-80 immunostaining. Blood 1996;87:284-91.

114. Pulford K, Lamant L, Morris SW, et al. Detection of anaplastic lymphoma kinase (ALK) and nucleolar protein nucleophosmin (NPM)-ALK proteins in normal and neoplastic cells with the monoclonal antibody ALK1. Blood 1997;89:1394-04.

115. Mino-Kenudson M, Chirieac LR, Law K, et al. A novel, highly sensitive antibody allows for the routine detection of ALK-rearranged lung adenocarcinomas by standard immunohistochemistry. Clin Cancer Res. 2010;16:1561-71.

116. Thunnissen E, Bubendorf L, Dietel M, et al. EML4-ALK testing in non-small cell carcinomas of the lung: a review with recommendations. Virchows Arch. 2012;461:245-57.

117. Paik JH, Choe G, Kim H, Choe JY, et al. Screening of anaplastic lymphoma kinase rearrangement by immunohistochemistry in non-small cell lung cancer: correlation with fluorescence in situ hybridization. J Thorac Oncol. 2011;6:466-72.

118. Zhang YG, Jin ML, Li L, et al. Evaluation of ALK rearrangement in Chinese non-small cell lung cancer using FISH, immunohistochemistry, and real-time quantitative RT- PCR on paraffin-embedded tissues. PLoS One. 2013;8:e64821. 
119. Wang R, Pan Y, Li C, Hu H, et al. The use of quantitative real-time reverse transcriptase PCR for 5' and 3' portions of ALK transcripts to detect ALK rearrangements in lung cancers. Clin Cancer Res. 2012;18:4725-32.

120. Geiss GK, Bumgarner RE, Birditt B, et al. Direct multiplexed measurement of gene expression with colorcoded probe pairs. Nat Biotechnol. 2008;26:317-25.

121. Peled N, Palmer G, Hirsch FR, et al. Next-generation sequencing identifies and immunohistochemistry confirms a novel crizotinib-sensitive ALK rearrangement in a patient with metastatic non-small-cell lung cancer. J Thorac Oncol. 2012;7:e14-6.

122. Christensen JG, Zou HY, Arango ME, et al. Cytoreductive antitumor activity of PF-2341066, a novel inhibitor of anaplastic lymphoma kinase and c-Met, in experimental models of anaplastic large-cell lymphoma. Mol Cancer Ther. 2007;6:3314-22.

123. Cui J. et al. Structure based drug design of crizotinib (PF-02341066), a potent and selective dual inhibitor of mesenchymal-epithelial transition factor (c-MET) kinase and anaplastic lymphoma kinase (ALK). Journal of medicinal chemistry 2011;54: 6342-63.

124. Zou HY, et al. An orally available small-molecule inhibitor of c-Met, PF-2341066, exhibits cytoreductive antitumor efficacy through antiproliferative and antiangiogenic mechanisms. Cancer Res 2007;67:4408-17.

125. Li C, Alvey C, Bello A, et al. Pharmacokinetics (PK) of crizotinib (PF-02341066) in patients with advanced nonsmall cell lung cancer (NSCLC) and other solid tumors. J Clin Oncol. 2011;29:e13065.

126. Kwak EL, Camidge DR, Clark J, et al. Clinical activity observed in a phase I dose escalation trial of an oral c-met and ALK inhibitor, PF-02341066. J Clin Oncol 27:15s, 2009 (suppl; abstr 3509).

127. Kwak EL, Bang YJ, Camidge DR, et al. Anaplastic lymphoma kinase inhibition in non-small-cell lung cancer. N Engl J Med. 2010;363:1693-703.

128. Shaw AT, Kim DW, Nakagawa K, et al. Crizotinib versus chemotherapy in advanced ALK-positive lung cancer. N Engl J Med. 2013;368:2385-94.

129. http://www.accessdata.fda.gov/scripts/cder/drugsatfda/ index.cfm?fuseaction=Search.DrugDetails

130. Malik SM, Maher VE, Bijwaard KE, et al. U.S. Food and Drug Administration Approval: Crizotinib for Treatment of Advanced or Metastatic Non-small Cell Lung Cancer that Is Anaplastic Lymphoma Kinase Positive. Clin Cancer Res. 2014, in press.

131. http://www.valuebasedcancer.com/article/crizotinibsuperior-chemotherapy-extends-median-survival-first-headhead-trial

132. Lis Y, Roberts MH, Kamble S, J Guo J, Raisch DW. Comparisons of Food and Drug Administration and European Medicines Agency risk management implementation for recent pharmaceutical approvals: report of the International Society for Pharmacoeconomics and outcomes research risk benefit management working group. Value Health. 2012;15:1108-18.

133. Katayama R1, Shaw AT, Khan TM, et al. Mechanisms of acquired crizotinib resistance in ALK-rearranged lung Cancers. Sci Transl Med. 2012;4:120ra17.

134. Choi YL, Soda M, Yamashita Y, et al. EML4-ALK mutations in lung cancer that confer resistance to ALK inhibitors. N Engl J Med. 2010;363:1734-9.

135. Sun HY1, Ji FQ. A molecular dynamics investigation on the crizotinib resistance mechanism of $\mathrm{C} 1156 \mathrm{Y}$ mutation in ALK. Biochem Biophys Res Commun. 2012;423:319-24.

136. Sasaki T, Koivunen J, Ogino A, et al. A novel ALK secondary mutation and EGFR signaling cause resistance to ALK kinase inhibitors. Cancer Res. 2011;71:6051-60.

137. Ji C, Zhang L, Cheng Y, Patel R, et al. Induction of autophagy contributes to crizotinib resistance in ALKpositive lung cancer. Cancer Biol Ther. 2014;15, in press.

138. Gettinger S, Weiss GJ, Salgia R, et al. A first in human dose finding study of the ALK/EGFR inhibitor AP26113 in patients with advanced malignanices. Ann Oncol 2012;(Supple.9):ix152-74.

139. Shaw AT, Camidge DR, Felip E, et al. Results of the first human phase I study of the ALK inhibitor LKD378 in advanced solid tumors. Ann Oncol 2012;(Supple9):ix152-74.

140. Seto T, Kiura K, Nishio M, Nakagawa K, et al. CH5424802 (RO5424802) for patients with ALK-rearranged advanced non-small-cell lung cancer (AF-001JP study): a single-arm, open-label, phase 1-2 study. Lancet Oncol. 2013;14:590-8.

141. Marsilje TH1, Pei W, Chen B, et al. Synthesis, structureactivity relationships, and in vivo efficacy of the novel potent and selective anaplastic lymphoma kinase (ALK) inhibitor 5-chloro-N2-(2-isopropoxy-5-methyl-4-(piperidin4-yl)phenyl)-N4-(2-(isopropylsulfonyl)phenyl)pyrimidine2,4-diamine (LDK378) currently in phase 1 and phase 2 clinical trials. J Med Chem. 2013;56:5675-90.

142. Kinoshita K1, Asoh K, Furuichi N, et al. Design and synthesis of a highly selective, orally active and potent anaplastic lymphoma kinase inhibitor (CH5424802). Bioorg Med Chem. 2012;20:1271-80.

143. Sakamoto H, Tsukaguchi T, Hiroshima S, et al. CH5424802, a selective ALK inhibitor capable of blocking the resistant gatekeeper mutant. Cancer Cell. 2011;19:679-90.

144. Lazzari C, Spitaleri G, Catania C, et al. Targeting ALK in patients with advanced Non Small Cell Lung Cancer: Biology, diagnostic and therapeutic options. Crit Rev Oncol Hematol. 2014;89:358-365.

145. Zhang S, Wang F, Keats J, et al. AP26113, a potent ALK inhibitor, overcomes mutations in EML4-ALK that confer resistance to PF-02341066 (PF1066). Cancer Research:2010;70(aupple 1; abstr. LB-298).

146. http://clinicaltrials.gov/show/NCT01685060

147. Zdzalik D, Dymek B, Grygielewicz P, et al. Activating 
mutations in ALK kinase domain confer resistance to structurally unrelated ALK inhibitors in NPM-ALKpositive anaplastic large-cell lymphoma. J Cancer Res Clin Oncol. 2014, in press.

148. Garcia-Carbonero R, Carnero A, Paz-Ares L. Inhibition of HSP90 molecular chaperones: moving into the clinic. Lancet Oncol 2013;14:e358-e369.

149. Mahalingam D, Swords R, Carew JS, et al. Targeting HSP90 for cancer therapy. Br J Cancer 2009; 100:1523-9

150. Neckers L, Workman P. Hsp90 molecular chaperone inhibitors: are we there yet? Clin Cancer Res. 2012;18:6476.

151. Normant E, Paez G, West KA, et al. The Hsp90 inhibitor IPI-504 rapidly lowers EML4-ALK levels and induces tumor regression in ALK-driven NSCLC models. Oncogene. 2011;30:2581-6.

152. Ying W, Du Z, Sun L, et al. Ganetespib, a unique triazolone-containing Hsp90 inhibitor, exhibits potent antitumor activity and a superior safety profile for cancer therapy. Mol Cancer Ther 2012; 11:475-84.

153. Sequist LV, Gettinger S, Senzer NN, et al. Activity of IPI504, a novel heat-shock protein 90 inhibitor, in patients with molecularly defined nonsmall-cell lung cancer. J Clin Oncol 2010; 28:4953-60.

154. Socinski MA, Goldman J, El-Hariry I, et al. A multicenter phase II study of ganetespib monotherapy in patients with genotypically defined advanced non-small-cell lung cancer. Clin Cancer Res 2013; 19:30680-77.

155. Felip E, Carcereny E, Barlesi F, et al. Phase II activity of the Hsp90 inhibitor AUY922 in patients with ALK rearranged $(\mathrm{ALK}+)$ or EGFR mutated advanced non small cell lung cancer (NSCLC). Ann Oncol 2012;(Suppl. 9):ix152-74.

156. Ying J, Guo L, Qiu T, Shan L, Ling Y, Liu X, Lu N. Diagnostic value of a novel fully automated immunochemistry assay for detection of ALK rearrangement in primary lung adenocarcinoma. Ann Oncol. 2013;24:2589-93.

157. Morey M1, Fernández-Marmiesse A, Castiñeiras D, et al. glimpse into past, present, and future DNA sequencing. Mol Genet Metab. 2013;110:3-24.

158. Broekman F, Giovannetti E, Peters GJ. Tyrosine kinase inhibitors: Multi-targeted or single-targeted? World J Clin Oncol. 2011;2: 80-93.

159. Looyenga BD, Cherni I, MacKeigan, JP, Weiss GJ. Tailoring Tyrosine Kinase Inhibitors to Fit the Lung Cancer Genome. Transl Oncol. 2011;4:59-70. 